\title{
Analyzing conductance correlations involved in recovery of bursting after neuromodulator deprivation in lobster stomatogastric neuron models
}

\author{
Kenneth Shim, Astrid A Prinz², Tomasz G Smolinski ${ }^{1^{*}}$ \\ From Twenty First Annual Computational Neuroscience Meeting: CNS*2012 \\ Decatur, GA, USA. 21-26 July 2012
}

In the crustacean stomatogastric ganglion (STG) functional neuronal activity can be produced with widely varying cellular parameter combinations. This variability has been observed in neurophysiological (e.g., [4]) and computational (e.g., [5]) studies. One possible mechanism responsible for this phenomenon is coregulation of ionic current levels. Although many relationships between ionic currents are cell-specific [6], some appear in several STG neurons. Those include the coregulation of the hyperpolarization-activated inward current, $\mathrm{I}_{\mathrm{h}}$, and the transient $\mathrm{K}^{+}$current, $\mathrm{I}_{\mathrm{A}}$, which affects neuronal firing properties [3], and the relationship between the delayed rectifier $\mathrm{K}^{+}$current, $\mathrm{I}_{\mathrm{Kd}}$, and the transient $\mathrm{Ca}^{2+}$ current, $\mathrm{I}_{\mathrm{CaT}}$, which affects the peak and duration of the slow-wave oscillation in bursting STG neurons [1]. Interestingly, ionic current coregulation depends on neuromodulation, not activity [2]. This is intriguing because the STG can recover function after neuromodulator deprivation (i.e., deafferentation). After the stomatogastric nerve, via which the STG receives neuromodulatory inputs, is cut or blocked, STG neurons initially lose their function. However, within $24 \mathrm{~h}$ to $96 \mathrm{~h}$, without external intervention, they again exhibit activity similar to that in intact STGs. The interplay between deafferentation, function recovery, and coregulation of ionic currents is under active research, which has so far produced interesting results showing that while some relationships are lost due to neuromodulator deprivation, some of them are altered (presumably to support

\footnotetext{
* Correspondence: tsmolinski@desu.edu

'Department of Computer and Information Sciences, Delaware State University, Dover, DE 19901, USA

Full list of author information is available at the end of the article
}

recovery) [8]. Here, we use a computational approach to study these phenomena in an important STG neuron, the anterior burster (AB). Previously, we explored a 12dimensional parameter space of an $A B$ model by simulating 21,600,000 parameter combinations [7]. Every parameter set was simulated and classified as functional if it produced realistic bursting activity and properly responded to deafferentation (i.e., became quiescent), which was simulated by removal of the modulatory proctolin current. Out of the $\sim 400,000$ models that failed the second criterion (i.e., exhibited non-quiescent behavior) we selected those that showed bursting $(\sim 14,000)$. We consider those models "recovered," as they function despite neuromodulation deprivation. By analyzing the parameter values in the "recovered" neurons, we investigate the impact of deafferentation on coregulations of ionic currents. We show that the relationship between $\mathrm{I}_{h}$ and $\mathrm{I}_{\mathrm{A}}$ is preserved regardless of the presence of neuromodulation, although the slope of the relationship is altered, which coincides with results from two other STG neurons [8]. We also observe the preservation of the $I_{K d}$ and $I_{C a T}$ relationship, albeit with an altered slope, which has not been reported in $\mathrm{AB}$ or any other STG neuron.

\section{Acknowledgements \\ Support: NSF HBCU-UP 0928404 to KS, BWF CASI Award to AAP, NSF EPSCOR 0814251 to TGS. \\ Author details \\ 'Department of Computer and Information Sciences, Delaware State University, Dover, DE 19901, USA. ²Department of Biology, Emory University, Atlanta, GA 30322, USA.}

Published: 16 July 2012 


\section{References}

1. Franklin CC, et al: Generation and preservation of the slow underlying membrane potential oscillation in model bursting neurons. J Neurophysiol 2010, 104:1589-1602.

2. Khorkova O, Golowasch J: Neuromodulators, not activity, control coordinated expression of ionic currents. J Neurosci 2007, 27(32):8709-8718.

3. MacLean JN, et al: Activity-independent coregulation of IA and Ih in rhythmically active neurons. J Neurophys 2005, 94(5):3601-3617.

4. Marder E, Goaillard JM: Variability, compensation and homeostasis in neuron and network function. Nat Rev Neurosci 2006, 7(7):563-574

5. Prinz AA, Billimoria CP, Marder E: Alternative to hand-tuning conductancebased models: Construction and analysis of databases of model neurons. J Neurophysiol 2003, 90:3998-4015.

6. Schulz DJ, Goaillard J-M, Marder E: Quantitative expression profiling of identified neurons reveals cell-specific constraints on highly variable levels of gene expression. Proc Natl Acad Sci (USA) 2007, 104:13187-13191.

7. Smolinski TG, et al: Systematic selection of model parameter values matching biological behavior under different simulation scenarios. BMC Neurosci 2008, 9(Suppl 1):P53.

8. Temporal $\mathrm{S}$, et al: Neuromodulation independently determines correlated channel expression and conductance levels in motor neurons of the stomatogastric ganglion. J Neurophysiol 2012, 107:718-727.

doi:10.1186/1471-2202-13-S1-P37

Cite this article as: Shim et al:: Analyzing conductance correlations involved in recovery of bursting after neuromodulator deprivation in lobster stomatogastric neuron models. BMC Neuroscience 2012 13(Suppl 1):P37.

\section{Submit your next manuscript to BioMed Central} and take full advantage of:

- Convenient online submission

- Thorough peer review

- No space constraints or color figure charges

- Immediate publication on acceptance

- Inclusion in PubMed, CAS, Scopus and Google Scholar

- Research which is freely available for redistribution

Submit your manuscript at www.biomedcentral.com/submit 